\title{
The Impact of Membership in Strategic Alliances on the Profitability of Firms in the Retail Sector
}

\section{Nikola Butigan}

Managing Director, Pemo Ltd., Dubrovnik, Croatia

nikola.butigan@pemo.hr

\section{Đuro Benić}

University of Dubrovnik, Department of Economics and Business Economics, Dubrovnik, Croatia

dbenic@unidu.hr
CroEconSur

Vol. 19

No. 2

December 2017

pp. $47-82$

Received: March 7, 2017

Accepted: October 18, 2017

Research Article

doi:10.15179/ces.19.2.2

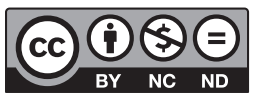

\section{Abstract}

Strategic alliances in the retail sector are based on cooperation in a variety of activities, ranging from supply and marketing to knowledge sharing and branding. For their members, they are a source of sustainable competitive advantage. Ever since the 1990s, a growing number of firms from the retail sector have attempted to improve their performance through participation in strategic alliances. The objective of this paper is to explore how participation in strategic alliances influences profitability of firms in the retail sector. A dynamic panel analysis is applied to the data on nearly 3,700 firms obtained from Amadeus, a large firm-level database, for eight countries (Croatia, Bosnia and Herzegovina, the Czech Republic, Slovakia, Slovenia, Poland, Hungary and Estonia) for the 2007-2012 period. The results of the investigation suggest that participation in strategic alliances positively influences a firm's performance. 
Keywords: strategic alliance, retail sector, profitability, panel analysis

JEL classification: D22, D74

\section{Introduction'}

Strategic alliances in the retail sector encompass cooperation in a variety of activities, from supply and marketing to knowledge sharing and branding. For their members, they are a source of sustainable competitive advantage. Ever since the 1990s, a growing number of firms from the retail sector have attempted to improve their performance through participation in strategic alliances. One of the most important reasons for participation in strategic alliances is improvement in firm performance. Among an array of performance indicators, the majority of authors emphasize the importance of profitability as the key indicator of performance and competitiveness in the long run (Buckley, Pass and Prescott, 1988; Stojčić and Vojvodić, 2012; Stojčić, 2012). In the long run, only profitable firms can survive, while their loss-making counterparts are forced to leave the market and face seizure of their market share by more competitive rivals. The importance of profitability also arises from the fact that accumulation of resources sets the foundations for expansion and development of new products and processes among business entities with barriers to accessing external finance.

The determinants of differences in profitability have been investigated by numerous academics. Traditional economics is largely of the opinion that differences in profitability are nothing more than a transitory feature of firm behavior. Alternative economic schools of thought point to numerous factors responsible for the ability of business entities to outperform their rivals. Cooperation among firms through institutionalized or noninstitutionalized venues such as strategic

1 An earlier version of this paper was presented at the $1^{\text {st }}$ International Conference "Smart Ideas and a New Concept of Economic Regeneration in Europe (SINCERE)”, held in Dubrovnik, Croatia, from September 28-October 1, 2016. 
alliances enables the creation of economies of scale and scope, knowledge and skill transfer, ease of access to a network of suppliers and distributors, removal of obstacles to financing and minimization of administrative costs. Such a form of cooperation is of particular relevance for small and medium sized enterprises. In penetrating markets these firms often have to confront numerous obstacles in obtaining financial, material or human resources.

The objective of this paper is to explore to what extent participation in strategic alliances influences the profitability of business entities in the retail sector of several Central, East and Southeast European countries (CESEE) (Croatia, Bosnia and Herzegovina, the Czech Republic, Slovakia, Slovenia, Poland, Hungary and Estonia) in the 2007-2012 period. To this end, the research aims to investigate whether participation in strategic alliances positively influences the profitability of firms. In doing so, the Amadeus database, which contains information on financial indicators, ownership, location and strategic alliance membership of business entities, is used. A dynamic panel methodology is applied to the dataset to control the dependence of profitability on its past realizations. The proposed methodology also enables control of time-invariant unobserved factors that influence profitability of business entities, such as quality of management or institutional framework features. Finally, the used methodology enables a distinction between short- and long-run determinants of profitability.

The use of a dynamic panel estimator in this paper represents, to the best of our knowledge, the first attempt of such kind in the literature on the behavior of business entities and the role of strategic alliances in the retail sector. The rest of the paper is structured as follows. The next section provides the theoretical framework of the investigation. Emphasis is placed on the theoretical reasoning about differences in profitability of business entities and the role of strategic alliances. A review of empirical literature is provided in section three, while the fourth section brings the model of investigation. The methodology is discussed in section five. The database and descriptives are provided in section six. The 
results of the investigation are presented in section seven. Finally, section eight concludes.

\section{Theoretical Framework}

Throughout the history of economic thought many academics have attempted to answer why some firms perform better than others. The results of their efforts are usually classified into two categories. Traditional, neoclassical economics sees differences in performance and competitiveness of business entities as a transitory feature of their behavior (Knight, 1921). In the neoclassical world of perfect competition, rational agents have all the relevant information to make optimal decisions in any given moment. In such a framework any source of superiority of some business entities over their rivals is of limited duration. Access to all the relevant information enables all business entities to appropriate benefits from each discovery. At the same time, market mechanisms perform a selection among business entities using two mechanisms. On the one hand, business entities unable to adjust to changes in their environment leave the market. On the other hand, the intensity of competition among remaining business entities leads to price reductions and erodes profits. Generally speaking, under the neoclassical framework, in the short run firms can achieve better results than their rivals, while in the long run the system as a whole, and business entities as its parts, aim to reach optimal efficiency and can achieve only normal profits.

Alternative economic schools suggest that differences in profitability are more than a transitory feature of a firm's behavior. These contributions depart from the assumptions about the perfect functioning of market mechanisms, rational economic agents and availability of all the relevant information. In conditions of market imperfections, agents have difficulties in accessing information and thus often make suboptimal decisions. Moreover, market imperfections often prevent diffusion of knowledge. As a consequence, agents in possession of new knowledge can create their own market niches and enjoy the benefits of monopolistic 
competition for a limited period of time. An important implication of alternative economic schools of thought is related to the temporal dimension of differences in performance and competitiveness of business entities. The ability of business entities to outperform their rivals is not perceived as transitory but rather as a process that stretches out in the long run. Among sources of competitive advantage these contributions name a number of elements in the behavior of business entities, their characteristics and features of their environment. In this sense, one can distinguish the contributions within Austrian economics, evolutionists and the resource-based approach.

For the Austrian economic school of thought, the differences in performance and competitiveness of firms are related to their motives for doing business (Von Mises, 1949; Kirzner, 1997). The possibility of above-average returns under market imperfections is the key driving force behind their activities and source of differences in profitability. Striving for higher profitability, according to such reasoning, encourages a quest for new knowledge, new ways of doing things, new markets and niches. Within such a framework firms try to organize their activities in new ways, whether these refer to changes in supply and distribution channels, knowledge and quality management or new methods for increasing employee efficiency such as trainings, integration of departments within the firm, changes in the decision-making process and new methods of interaction with the environment, such as participation in strategic alliances or delegation of activities to cooperating business entities. Moreover, business entities have an incentive to differentiate from their rivals through investment in advertising, different pricing methods, changes in sales range and other marketing activities. The Austrian school postulates that the above-mentioned activities provide a means of creating such a product offer that will either underprice rivals or offer products of superior quality.

The previously described sources of competitive advantage are of limited duration. Diffusion of knowledge cannot be permanently prevented and knowledge about sources of supremacy eventually becomes accessible by rivals. Changes 
in consumer tastes, availability of new technologies and changes in availability of inputs pave the way for entrance of new ideas and new rivals in the branch. The essence of this process was described by Schumpeter (1942) as a creative destruction process. At its core is the continuing substitution of existing products and services with new ones. Such a process requires complex decisions that have to take into account the relationships with the environment, as well as strategic and technological factors. Moreover, the long-term survival of business entities requires continuous upgrading of activities and introduction of new product, process, organizational and marketing innovations.

The effect of innovations on the differences in profitability of business entities is a recurring topic throughout the contributions of many other alternative economic schools. The evolutionary approach draws an analogy between the behavior of species in nature and firm survival. The starting point of this approach is the assumption about the interdependence between the survival chances of individual species and their ability to adapt to conditions in their environment. At some point, the compatibility between the characteristics of the species and the conditions around them determines the prospects of their survival. Over longer periods of time, the chances of survival increase for adapting species. Building on these foundations, evolutionary economics suggests that outperforming of rivals will be a feature of those business entities whose characteristics are compatible with the challenges of their environment (Alchian, 1950; Nelson and Winter, 1982). The adjustment process takes place through the innovation efforts of the business entities. Firms that are better at adapting have higher prospects of above-average returns and market expansion at the expense of less efficient rivals.

Differences in firm performance and competitiveness have been the subject of investigation within management as well. The resource-based approach (Barney, 1991; Kogut and Zander, 1992) relates profitability of business entities with their ability of market differentiation. According to this approach, the sources of differentiation can be found within firm characteristics, features of their behavior and elements of their environment. To this end, the importance of skills, 
organization processes, information, knowledge and all other factors that can be used as sources of supremacy over rivals is emphasized (Daft, 1986). Depending on the different ways firms use their resources for the purpose of differentiation and gaining competitive advantage over rivals, we can distinguish two forms of market competition. On the one hand, the use of existing resources enables firms to build price competitiveness. Such a strategy, however, is of limited duration since business entities can remain profitable only to a certain level, after which they face loss. On the other hand, development of new products, services and processes as well as the introduction of marketing and organizational innovations provide the ability to compete in the quality segment of the market. Such a mode of competition is characterized by high levels of added value and above-average returns over longer periods of time.

The impact of strategic alliances on a firm's performance and competitiveness can be explained in several ways. According to the resource-based view, the key reason for the emergence of strategic alliances is the dispersion of resources across firms, where resources are defined as financial, technological, managerial and other relevant resources. In building their competitiveness, business entities can rely either on internal resources or they can merge their resources with those of their rivals in order to improve their performance (Das and Teng, 2000). One way of joining resources is building strategic alliances. To this end, participation in a strategic alliance is a way of gaining access to valuable resources of other business entities in order to maximize returns on one's own resources. Lado, Boyd and Hanlon (1997) note that alliances with rivals increase profitability through joint effects of learning and resource sharing.

Generating positive synergy effects depends on a number of factors that fall under the common denominator of resource complementarity. The complementarity of resources refers to such a combination of resources whose joining together leads to maximization of performance. The above-mentioned suggests that creating a strategic alliance provides business entities with access to resources that otherwise would not be possible. These resources can take a variety of forms 
such as knowledge about the market, access to distribution channels, financial and technical resources and market position (Hitt et al., 2000; Lee, 2007). In addition to resource complementarity, the achievement of synergy effects in terms of profitability is determined also by partner characteristics. Luo, Rindfleisch and Tse (2007) note that strategic alliance effects on profitability can also be negative if the motive for joining is acquisition of resources that consequently enable independent market entry. Moreover, the fear of opportunistic behavior can prevent a complete joining of resources and erode the profitability of each alliance member. Finally, the impact of a strategic alliance on the performance of its members depends on the absorption capacity of the firm. The ability to recognize external resources, potential for their application within the firm and commercialization determine the direction and intensity of the effect of the strategic alliance on performance (Lee, 2007).

The impact of strategic alliances on profitability can also be observed through the prism of transaction costs economics. Entering into a strategic alliance, according to this approach, is motivated by the existence of market imperfections. On the one hand, strategic alliances enable business entities to avoid the risk of opportunistic behavior in market transactions and thus positively influence profitability. On the other hand, the existence of market imperfections can lead to a negative influence of the strategic alliance on particular members. Functioning of the strategic alliance depends on the previously defined contract. The adverse effect of bounded rationality on the possibility of realization of all possible outcomes creates an incentive for opportunistic behavior and thus increases the costs of contracts, partner judgments and monitoring (Oum et al., 2004). Finally, strategic alliances complicate decision making, disrupt the division of activities (i.e., defining which activities are performed jointly and which are undertaken by each alliance member individually) and raise the intensity of communication. Together, all of the above issues raise coordination costs (Gulati and Singh, 1998). Therefore, the transaction costs theory suggests 
that the impact of strategic alliances on their members will be positive only if the potential benefits outweigh the costs of participation.

Broadly speaking, participation in a strategic alliance can influence the performance and competitiveness of its members in two ways (Harrigan, 1986; Porter and Fuller, 1986; Oum et al., 2004). On the one hand, an alliance with other business entities leads to cost gains through economies of scale, cost sharing, risk pooling, economies of learning and access to new skills, all of which together increase profitability. On the other hand, participation in a strategic alliance improves the negotiating position of the alliance member against its suppliers due to increased orders of materials, equipment and parts. Finally, participation in a strategic alliance enables an improvement in market position through innovativeness, new market entry and other strategic activities, which in the end positively influence profitability. However, apart from these benefits, participation in strategic alliances increases the costs of monitoring and coordination, and thus generates an adverse effect on profitability.

\section{Literature Review}

Previously mentioned theoretical propositions have paved the way for a vast number of empirical studies. The search for determinants of profitability has developed in several directions. The largest number of studies are founded in industrial economics. This stream of research attempts to answer whether aboveaverage returns represent a transitory feature of firm behavior or they persist in the long run as well. Research based on the structure conduct performance (SCP) paradigm is concerned with the impact of industrial characteristics, such as concentration, technological and knowledge intensity or barriers to entry, on profitability. The third line of investigation deals with characteristics of business entities such as their size, innovativeness, experience, ownership or market orientation. Finally, the work of some authors emphasizes the connection between profitability and inter-organizational relationships such as strategic alliances. 
On the one hand, existing studies investigate differences in the profitability of business entities participating in strategic alliances and those that enter the market on their own. The subject of investigation in other studies is the impact of strategic alliance characteristics on the performance and competitiveness of the alliance members.

The research on persistence of profitability departs from the thesis about the corrective functioning of market forces on deviations in returns accrued by firms. Findings from a large number of countries support the arguments in favor of persistent profitability differences in the long run (Cubbin and Geroski, 1990; McMillan and Wohar, 2011). Similar findings are obtained with the use of panel econometric techniques across industries in both developed and developing countries (Goddard, Tavakoli and Wilson, 2005; Stojčić and Vojvodić, 2012). Findings from the latter line of research are particularly relevant as they enable the differentiation between short- and long-run effects of particular determinants on the profitability of business entities. Explanations for the above findings have been attributed to a large number of factors, such as industry characteristics, features of business entities and institutional factors. Early research in this field suggests that market concentration positively influences profitability of business entities (Bain, 1951; 1956). In the decades that have followed, these early findings have been subject to much criticism, mostly related to model construction, level of data aggregation and potential endogeneity of market structure in relation to profitability. More recent research seems to contradict these early findings as well. Using data from 14 countries in the 1994-1998 period, Slade (2004) reports a positive impact of industrial concentration on the profitability of business entities. Lin, Yang and Arya (2009) do not find a statistically significant relationship between concentration and performance of business entities in the USA over a decade-long period.

Profitability of business entities is related to their market share as well. Several authors report the positive influence of market power on profitability (Goddard, Tavakoli and Wilson, 2005; Slade, 2004; Stojčić and Vojvodić, 2012). On the 
one hand, such findings can be taken as evidence of the ability to undertake uncompetitive practices by business entities with greater market power. On the other hand, the positive relationship between market share and profitability in a dynamic framework can be interpreted as the consequence of improvements in the efficiency of business entities, whereas the most efficient firms are provided with an opportunity to seize the market share of their rivals and achieve aboveaverage profits. However, it needs to be clarified that the impact of market power on profitability can also be negative when firms follow 'quiet life' behavior and enjoy the fruits of their past activities.

In looking for the determinants of profitability, researchers have turned not only to industrial characteristics but to the characteristics of business entities as well. One of the questions in this context is the relationship between size and profitability of firms. A larger size of the firm signals the ability to exploit economies of scale. Goddard, Tavakoli and Wilson (2005), however, note that larger business entities can be less agile in adjustment to market challenges and prone to the 'quiet life' behavior, thus achieving lower rates of profitability. The results of empirical studies do not provide unanimous support to either of the above theses. The majority of studies report a positive relationship between firm size and profitability (Luo, Rindfleisch and Tse, 2007; Lin, Yang and Arya, 2009). However, the findings of Goddard, Tavakoli and Wilson (2005) from Belgium, France, Italy, Spain and the United Kingdom suggest an inverse relationship between profitability and firm size. This can be taken as evidence in support of the 'quiet life' theory. Finally, Oum et al. (2004) do not find evidence of a relationship between firm size and profitability.

Among sources of profitability some authors highlight the role of innovations. Ever since Schumpeter (1942), economists have argued that within imperfectly competitive markets innovations act as a disruptive force that destroys existing economic structures and paves the way for the emergence of new ones. Throughout this process, business entities are provided with an opportunity to sell their products at a price exceeding marginal costs and thus accrue above-average 
returns. Empirical research abounds with evidence in support of this thesis (Grossman and Helpman, 1994; Lööf and Heshmati, 2002; 2006; Hashi and Stojčić, 2013). Moreover, Zollo, Reuer and Singh (2002) report a positive impact of investment in research and development on firms in the biotechnological and pharmaceutical industries within a decade-long framework.

Several studies have addressed the relationship between ownership and profitability. The existing literature, particularly that focused on Central, East and Southeast European economies, associates foreign ownership with enterprise restructuring, technology and knowledge transfer, and improvements in export competitiveness, all of which positively influence profitability (Djankov and Murrell, 2002; Anić and Nušinović, 2003; Rugraff, 2006; Dunković, 2017). Besides the direct impact of foreign direct investment on business entities, existing research has also addressed other dimensions of this process. Oum et al. (2004) find no relationship between the share of public ownership in firms and their profitability. Stojčić and Vojvodić (2012) investigate the impact of foreign ownership on profitability of firms in the retail sector. Their findings indicate that a larger presence of foreign firms acts as an incentive for domestic firms to scale down their prices and thus negatively influences profitability. These findings are consistent with the ones reported by Anić and Nušinović (2003), although for an earlier time period.

Existing studies address the impact of the external environment on profitability in several ways. Luo, Rindfleisch and Tse (2007) explore how the performance of firms is affected by uncertainty and market turbulences, defined as changes in the customer base, and by the velocity of technological change. Their findings suggest that a higher degree of uncertainty negatively affects profitability, while the contribution of technological changes is positive. Lin, Yang and Arya (2009) investigate the impact of environment dynamics defined as the degree of uncertainty over the forecast of future revenues. They find a negative impact on profitability, which can be taken as evidence that survival in a dynamic environment requires a high degree of flexibility and adaptation. Finally, Stojčić 
and Vojvodić (2012) investigate the impact of agglomeration externalities such as knowledge sharing and cooperation with professional and scientific institutions. Their findings suggest that cooperation with agents from the external environment positively influences profitability.

Within the existing literature the question of profitability is investigated in the context of cooperation between business entities in strategic alliances. The research in this field has developed in three directions. One group of authors is interested in the differences in profitability between members and non-members of strategic alliances (Reijnders and Verhallen, 1996; Oum et al., 2004). The research of a second group of authors is focused on the relationship between strategic alliance characteristics and profitability (Zollo, Reuer and Singh, 2002; Lu and Beamish, 2006). Finally, the largest number of studies aim to answer which strategic alliance characteristics affect the profitability of the alliance members and in what way (Bae and Gargiulo, 2004; Lee, 2007; Goerzen, 2007; Luo, Rindfleisch and Tse, 2007; Antoncic and Prodan, 2008; Lin, Yang and Arya, 2009). While revealing a substantial amount of information about the impact of strategic alliances on firm performance, existing studies are mostly based on simple analytical methods that question the validity of their findings.

Findings from the first group of studies mostly confirm the positive impact of strategic alliance participation on profitability. Reijnders and Verhallen (1996) analyze differences in profitability and productivity among strategic alliance members and independent business entities within the Dutch retail sector. Their findings reveal superiority of strategic alliance members in terms of both productivity and profitability. Oum et al. (2004) are concerned with the impact of strategic alliances on productivity and profitability of the airline industry during the 1986-1995 period. Their findings point on the one hand to the favoring role of strategic alliances in productivity. On the other hand, the impact on profitability depends on the extent of cooperation within the alliance. A greater degree of cooperation facilitates the profitability of member firms. Such a finding is interpreted as evidence that greater intensity of cooperation among 
strategic alliance members paves the way for knowledge transfer, cost sharing, risk diversification and general resource joining.

Research on the relationship between strategic alliance characteristics and profitability is mostly focused on the functioning of the alliances and their characteristics, such as size or ownership stakes of the partners. Zollo, Reuer and Singh (2002) investigate the impact of within-alliance processes on performance using a sample of strategic alliances within the biotechnological industry. The model of investigation controls for previous experience of partners with other alliance members, experience of cooperation with firms within the same industry and control of capital integration within the strategic alliances. The obtained findings do not support the impact of previous alliance experience and cooperation with business entities from the same field. However, a history of cooperation with other members of the strategic alliance positively influences profitability. Among other factors, subsequent alterations of the alliance agreement do not influence profitability, while the impact of monitoring mechanisms is positive.

Besides alliances within national borders, the relationship between strategic alliance characteristics and profitability is analyzed in the international context as well. Lu and Beamish (2006) investigate the impact of international alliances between small and medium sized Japanese business entities and their partners in 43 countries. Knowledge about foreign markets does not influence strategic alliance profitability, but it has an adverse effect on the durability of the alliance. The size of business entities has a negative impact on the profitability and duration of the alliance.

As mentioned, the largest proportion of studies deal with the impact of strategic alliances on the profitability of their members. Bae and Gargiulo (2004) explore the impact of alliance member substitutability and structure on the profitability of the telecommunications sector. The findings suggest that larger market share of business entities increases propensity towards participation in strategic alliance. Such a finding is taken as evidence of an oligopolistic motive for 
cooperation. Furthermore, market power of partners and their substitutability are not found to be significant. The network density of business entities, defined as the relationship between maximum and actual number of alliances, negatively influences profitability. Lee (2007) explores how the characteristics of strategic alliances influence profitability of small and medium sized enterprises in the biotechnological industry. The model, which includes partner characteristics, structure and type of alliance, relationship with partners and absorptive capacity, suggests that all of the above-mentioned factors positively influence the profitability of an alliance.

Existing studies suggest that business entities often join strategic alliances with partners with whom they have a history of cooperation. Goerzen (2007) explores the impact of this feature on profitability. The results indicate that multiple strategic alliances with identical partners have a negative effect on profitability. This effect is particularly strong in settings with high technological uncertainty and interdependence of different technological fields. Luo, Rindfleisch and Tse (2007) investigate the impact of alliances among rivals. The effect is nonlinear with a negative sign at low and high levels of association, while the opposite is the case at moderate levels. Antoncic and Prodan (2008) analyze the relationship between participation in strategic alliances, development of corporate entrepreneurship and performance of business entities within the manufacturing sector in Slovenia. The results of the investigation reveal that corporate entrepreneurship facilitates profitability. In turn, the development of corporate entrepreneurship is related to the intensity of efforts of the alliance members and to the degree of compatibility of norms, values and cultural patterns between partners. Lin, Yang and Arya (2009) note that the complementarity of resources invested in the alliance by partners as well as partner reputation have a positive impact on profitability. The latter holds among business entities with bad reputation, in alliances characterized by reputation asymmetry and among young business entities. 
Existing studies reveal numerous determinants of profitability. However, as previously mentioned, the majority of findings derive from simple analytical methods that do not take into account the persistence of profitability or the potential endogeneity of the relationship between profitability and its determinants. A relatively modest proportion of studies are focused on the retail sector and the differences in profitability among strategic alliance member and non-member firms within this sector. The lack of studies dealing with the mentioned topic is particularly evident in the context of Central, East and Southeast European countries such as Croatia, where to the best of our knowledge no studies exist that deal with the impact of strategic alliances on profitability of firms in the retail sector. The rest of the paper aims to fill this gap.

\section{Model of Investigation}

For the purpose of this investigation, a model is developed that in general form can be expressed as:

$$
P f_{i t}=P f_{i t-1}, S A_{i t}, X_{i t} \text {. }
$$

The dependent variable in equation (1) is the indicator of profitability defined as return on assets (ROA) of firm $i$ from the retail sector in year $t$. The right side of the equation includes the lagged value of the dependent variable, which controls the dependence of profitability on its past realizations. Variable $S A_{i t}$ is the categorical variable taking the value of 1 if the firm is a member of the strategic alliance. A positive sign is expected on this variable.

The term $X_{i t}$ in equation (1) stands for a number of control variables, which include firm characteristics, industry characteristics and features of the firm environment. Among the firm characteristics, the model includes size, ownership and two measures of cost efficiency. Size of the firm is measured by the number of employees. On the one hand, the firm size can be associated with the ability to impose barriers to entry, ease of access to resources and innovativeness. On the 
other hand, larger firms, due to organizational complexity, can also be less flexible in their response to challenges of the environment, which can exert adverse effect on their profitability. For these reasons, there is no a priori expectation on the sign of this variable.

Firm ownership is defined as the categorical variable taking the value of 1 if the firm is predominantly foreign-owned. Inflow of foreign direct investment in Central, East and Southeast European countries has been found to have a positive impact on the firm's restructuring, competitiveness and productivity growth (Djankov and Murrell, 2002; Rugraff, 2006; Schadler et al., 2006). All of the aforementioned processes facilitate the firm's performance, for which reason a positive sign can be expected. However, evidence from some countries such as Croatia reveals that increase in foreign direct investment in the retail sector results in stronger competition and price reduction, which has a negative impact on profitability (Stojčić and Vojvodić, 2012). For these reasons, no a priori expectation is made regarding the sign of this variable.

Cost efficiency is modelled with two variables. Unit labor costs are defined as the ratio between total labor costs and firm revenues, while unit material costs are defined as the ratio between total material costs and firm sales revenues. In the existing literature, unit costs reduction is generally interpreted as an indicator of better cost efficiency (Havlik, 2000; Stojčić, Hashi and Telhaj, 2013). Under the assumption of price stability, such a development can lead to a higher profit margin, for which reason a negative sign should be expected on these variables.

Among industry characteristics, the model includes industrial concentration measured by the Herfindahl-Hirschman index. A positive sign of this variable could be taken as evidence that in more concentrated industries the potential for higher profitability is greater due to factors such as barriers to entry or economies of scale. Two variables are included to control the impact of agglomeration externalities on the firm's profitability. There are several reasons why these externalities should positively influence profitability. According to Marshall 
(1920), the firm's location in densely populated urban areas provides access to greater demand, better pool of labor and more developed infrastructure such as scientific and professional institutions and transport infrastructure. Jacobs (1969) emphasizes the importance of within-industry externalities of spatial concentration in building firm competitiveness, such as ease of access to specialized inputs or labor force.

More recent contributions in this field emphasize the maturity of the interfirm information network. According to this explanation, business activity in a particular geographic area takes place according to a set of formal and informal rules. In search of knowledge and information, and through contacts with other economic agents, firms rely on these rules. Changing the existing information network requires investment, both in terms of acquisition of knowledge and adjustment, which may exert a negative effect on profitability. Bearing this in mind, a positive effect of agglomeration externalities on the firm's profitability can be expected.

Table 1: Variable Description

\begin{tabular}{|c|c|}
\hline$P f_{i t}$ & Return on assets of firm $i$ in year $t(R O A)$ \\
\hline$S a_{i t}$ & Categorical variable; 1 if member of the strategic alliance \\
\hline $\mathrm{Size}_{i t}$ & Number of employees of firm $i$ in year $t$ \\
\hline Ownership & Categorical variable; 1 if foreign-owned \\
\hline $\mathrm{ULC}_{i t}$ & Unit labor costs; labor costs/turnover of firm $i$ in year $t$ \\
\hline $\mathrm{UMC}_{i t}$ & Unit material costs; material costs/turnover of firm $i$ in year $t$ \\
\hline$H H_{i t}$ & Industrial concentration; Herfindahl-Hirschman index \\
\hline Urbanization externalities & Number of all firms in region/number of all firms in country \\
\hline Localization externalities & Number of retail firms in region/number of all firms in region \\
\hline Country $_{i t}$ & Categorical variables for countries included \\
\hline
\end{tabular}

Source: Authors.

Building on what was previously said, the model includes variable urbanization externalities defined as the ratio between all firms within a certain region and all firms within the country in order to control the between-industry effects. 
It also includes variable localization externalities defined as the ratio between retail firms and all firms in the region in order to control the within-industry externalities. A positive sign is expected for both variables. Finally, the model includes a group of categorical variables that control the country-specific effects for all countries whose firms are included in the analysis. The list of variables is presented in Table 1.

\section{Methodology}

The methodology of investigation is chosen based on model characteristics and the nature of the dataset. The longitudinal (panel) nature of the database suggests that the suitable estimator should be selected from the family of panel estimators. In addition, it should be taken into account that the existing level of the dependent variable depends on its past realizations. Finally, one needs to bear in mind that the effect of strategic alliance on profitability does not take place instantaneously but during time. The latter implies that a distinction should be made between short- and long-run effects of regressors on the dependent variable.

Bearing in mind what was previously said, the analysis is based on the dynamic panel estimation technique (Arellano and Bond, 1991; Blundell and Bond, 1998). This method is part of a larger family of estimators known as the generalized method of moments (GMM). In the presence of endogeneity, the dynamic panel estimator can yield unbiased and consistent coefficients based on instruments found within the system. In general form the dynamic model can be defined as:

$y_{i t}=\alpha y_{i t-1}+\beta x_{i t}+u_{i}+v_{i t}$,

where $y_{i t}$ stands for the dependent variable of firm $i$ in period $t ; y_{i t-1}$ is the lagged value of the dependent variable; $x_{i t}$ is a vector of independent variables for firm $i$ in period $t ; u_{i}$ refers to time-invariant effects and $v_{i t}$ is idiosyncratic error.

Individual effects are treated as stochastic, while it is assumed that there is no serial correlation between errors. In equation (2), time-invariant effects $u_{i}$ are, 
by definition, correlated with values of the dependent variable in all periods (including the lagged dependent variable on the right-hand side that implies existence of potential endogeneity). This problem is solved with the differencing of equation (2), which takes the form of:

$\Delta y_{i t}=\alpha \Delta y_{i t-1}+\beta \Delta x_{i t}+\Delta v_{i t}$.

In equation (3) time-invariant effects are removed, but the problem of endogeneity persists due to the correlation between the differenced value of the lagged dependent variable and idiosyncratic error term (through correlation between $y_{i t-1}$ and $v_{i t-1}$. However, in the absence of serial correlation between errors, lagged levels of the endogenous variable (e.g., $y_{i t-2}$ ) and lagged differences of these variables (e.g., $\Delta y_{i t-2}$ ) can be used as instruments (Arellano and Bond, 1991; Greene, 2002). The same principle holds for instrumenting other potentially endogenous variables.

The dynamic panel estimator can take two forms: differenced and system estimator. As noted by Blundell and Bond (1998), the differenced estimator can yield biased and inefficient results when lagged levels of the dependent variable are close to random walk. In such situation, lagged differences of the endogenous variable have greater power to predict actual levels than lagged levels have to predict actual differenced values. In such case, the system estimator is superior. This estimator builds a database with double the amount of observations for levels and differences equations. Nevertheless, the system is treated as a single equation under the assumption that the same linear relationship and estimated coefficients hold for transformed (differenced) and nontransformed (levels) equations (Roodman, 2009). Another advantage of the system estimator is the ability to include categorical variables. The difference estimator would eliminate these variables together with time-invariant effects. Finally, the system estimator relies on a larger number of instruments than its differenced counterpart, which increases the amount of available information and leads to more efficient estimation. 
Dynamic models can be estimated in one-step and two-step procedures. In the case of the former, the estimator is sensitive to the heteroscedasticity. In order to yield a robust estimator, another step is introduced in the procedure. This uses residuals from the first step to construct a matrix robust to heteroscedasticity patterns (Roodman, 2009). However, standard errors obtained this way can be downward biased. This problem can be solved with the use of Windmeijer (2005) corrections, which are applied in this research.

Finally, the dynamic analysis enables a distinction between short- and longrun effects of explanatory variables on the dependent one. In equation (2) the short-run coefficient $\beta$ represents only a fragment of the total change (Greene, 2002). The long-run effect can be calculated mathematically as a product of this coefficient and a long-run multiplier. Standard error and t-statistics for this coefficient can be calculated with the use of the delta method (Papke and Wooldridge, 2005).

\section{Dataset}

For the purpose of this research, data was taken from the Amadeus database on firms from eight countries including Croatia, Bosnia and Herzegovina, Hungary, the Czech Republic, Slovakia, Slovenia, Poland and Estonia. The analysis was undertaken on the sample of firms covering the 2007-2012 period. The number of firms varies across countries and time as can be seen in Table 2 .

The Amadeus database contains information on the firm's membership in strategic alliances. These data were complemented with information from individual strategic alliances in the analyzed countries about their member firms in order to extend the list of strategic alliance members. Finally, a survey was carried out on the remaining firms, which were contacted via email and asked about their membership in strategic alliances. A final list of strategic alliance members was formed in this way. Table 3 brings information on membership 
of the analyzed firms in strategic alliances. From there it can be seen that the number of such firms varies from 8 percent in Slovenia to 45 percent in Hungary.

Table 2: Number of Firms in the Sample

\begin{tabular}{|c|c|c|c|c|c|c|}
\hline & 2007 & 2008 & 2009 & 2010 & 2011 & 2012 \\
\hline Croatia & 1,771 & 1,700 & 1,799 & 1,903 & 1,730 & 1,642 \\
\hline Bosnia and Herzegovina & 228 & 236 & 233 & 234 & 505 & 207 \\
\hline The Czech Republic & 157 & 129 & 106 & 136 & 168 & 156 \\
\hline Slovakia & 561 & 615 & 674 & 964 & 929 & 911 \\
\hline Slovenia & 128 & 129 & 123 & 141 & 278 & 287 \\
\hline Hungary & 100 & 98 & 114 & 105 & 117 & 142 \\
\hline Poland & 271 & 237 & 245 & 283 & 295 & 286 \\
\hline Estonia & 134 & 135 & 138 & 168 & 224 & 222 \\
\hline Total & 3,350 & 3,279 & 3,432 & 3,934 & 4,246 & 3,853 \\
\hline
\end{tabular}

Source: Authors' calculations.

Table 3: Firms Participating in Strategic Alliance, \% of Sample

\begin{tabular}{|c|c|}
\hline Country & $\%$ \\
\hline Croatia & 20.46 \\
\hline Bosnia and Herzegovina & 15.76 \\
\hline The Czech Republic & 30.22 \\
\hline Slovakia & 16.61 \\
\hline Slovenia & 8.29 \\
\hline Hungary & 44.67 \\
\hline Poland & 31.42 \\
\hline Estonia & 20.37 \\
\hline
\end{tabular}

Source: Authors' calculations.

A descriptive analysis of profitability between firms that participate on the market individually and those that are part of strategic alliances reveals heterogeneous results. On the one hand, in Croatia, Slovakia, Slovenia and Poland firms that do their business alone are less profitable than strategic alliance members. In Bosnia and Herzegovina, the Czech Republic, Hungary and Estonia findings suggest that firms outside of strategic alliances perform better. Finally, when an overall 
sample is taken into consideration, strategic alliance members outperform other firms.

Table 4: Profitability and Strategic Alliance Membership, 2007-2012

\begin{tabular}{l|c|c}
\hline \multirow{2}{*}{ Country } & Strategic alliance membership, in \% \\
\cline { 2 - 3 } & No & Yes \\
\hline Croatia & -0.94 & 0.89 \\
\hline Bosnia and Herzegovina & 5.75 & 4.79 \\
\hline The Czech Republic & 0.09 & 0.03 \\
\hline Slovakia & 2.56 & 4.1 \\
\hline Slovenia & 1.61 & 2.47 \\
\hline Poland & 8.22 & 8.36 \\
\hline Hungary & 0.14 & 0.11 \\
\hline Estonia & 3.07 & 2.75 \\
\hline Total & 1.53 & 2.54 \\
\hline
\end{tabular}

Source: Authors' calculations.

\section{Results}

The investigation of the relationship between participation in strategic alliances and profitability of firms in the retail sector of Central, East and Southeast European countries is based on the dynamic panel estimation of the model that in general form can be defined as:

$$
\begin{aligned}
P f_{i t}= & c+\alpha P f_{i t-1}+\beta_{1} S A_{i t}+\beta_{2} \ln S_{i z e_{i t}}+\beta_{3} \ln U L C_{i t}+\beta_{4} \ln U M C_{i t}+ \\
& +\beta_{5} O w n_{i t}+\beta_{6} \ln H H I_{i t}+\beta_{7} \ln L o c_{i t}+\beta_{8} \ln U r b_{i t}
\end{aligned} .
$$

In equation (4) the dependent variable is defined as return on assets (ROA) of firm $i$ in year $t$. As this variable can take both positive and negative values, it enters the model in original form. The right-hand side of the equation includes the lagged value of the dependent variable and the categorical variable, which takes the value of 1 if the firm is a member of a strategic alliance in the given year $(S A)$. The model also includes a number of variables that control the firm's characteristics. Size of the firm (lnSize) is defined as the natural logarithm of the number of employees in firm $i$ in year $t$. Unit labor and material costs $(\ln U L C$ and $\ln U M C)$ enter the model as natural logarithms of the ratio between employee and material 
costs and firm revenues. The model also includes a categorical variable for foreign ownership (Own), which takes the value of 1 if more than 25 percent of the firm is controlled by a foreign owner.

Among variables controlling the features of the firm's environment, industrial concentration is measured by the natural logarithm of the Herfindahl-Hirschman index $(\ln H H I)$, while localization $(\ln L o c)$ and urbanization economies $(\ln U r b)$ are measured by natural logarithms of ratios between firms in a given industry and total number of firms in the region, and between all firms in the region and total number of firms in the country, respectively. Country-specific characteristics are controlled with the categorical variables where Croatia is taken as the base category. The model also includes a range of categorical variables for analyzed years. The purpose of these variables is to control cross-sectional dependence patterns. Roodman (2009) notes that such dependence may arise due to universal cross-sectional shocks.

The model is estimated with the econometric program Stata 13, where the lagged dependent variable is treated as predetermined and instrumented with its own lagged differences and lagged levels. Other exogenous variables enter the model on their own. For expositional convenience, the following section presents the findings for key variables of interest, while the coefficients for annual categorical variables are left out. ${ }^{2}$

\subsection{Discussion of Findings}

The starting point of the econometric analysis is the examination of model diagnostics. The most important diagnostic issue in the context of dynamic panel analysis is the validity of the chosen instruments. In the system GMM estimation, these are found within the system. In the levels equation, differences of predetermined and endogenous variables lagged by two or more periods are used as instruments. In the differenced equation, predetermined and endogenous 2 Detailed printouts of estimations are available upon request. 
variables are instrumented with their levels lagged by two or more periods. To test the validity of the instruments, the Hansen test of over-identifying restrictions and the Arellano-Bond test for autocorrelation of residuals are used. The null hypothesis of valid restrictions in the Hansen test cannot be rejected.

A further important diagnostic tool for dynamic panel analysis is the $\mathrm{ml} / \mathrm{m} 2$ test for autocorrelation of residuals (Arellano and Bond, 1991). The purpose of this test is to determine the presence of first and second order autocorrelation in the error term of the differenced equation. In the absence of second order autocorrelation, the levels of potentially endogenous lagged variables can be considered a valid instrument. Table 5 reveals that the hypothesis of no autocorrelation of first order can be rejected with high probability, while there is insufficient evidence to reject the hypothesis about second order autocorrelation.

Table 5: Model Diagnostics

\begin{tabular}{|c|c|}
\hline Diagnostics & Value \\
\hline Number of observations & 22,094 \\
\hline Number of groups (firms) & 6,588 \\
\hline Number of instruments & 31 \\
\hline Wald test & $1,404.40^{* * *}$ \\
\hline Hansen $J$ test & 10.61 \\
\hline $\mathrm{p}>\operatorname{chi} 2$ & 0.30 \\
\hline Arellano-Bond test first order & -16.97 \\
\hline $\mathrm{p}>$ chi2 & 0.000 \\
\hline Arellano-Bond test second order & 1.52 \\
\hline $\mathrm{p}>$ chi2 & 0.129 \\
\hline Lagged dependent variable: fixed effects panel & $0.003^{* * *}$ \\
\hline Lagged dependent variable: dynamic panel & $0.29^{* * *}$ \\
\hline Lagged dependent variable: OLS & $0.51^{* * *}$ \\
\hline
\end{tabular}

Note: ${ }^{* * *},{ }^{* *}$ and ${ }^{*}$ denote a statistical significance at 1,5 and 10 percent level, respectively. Source: Authors' calculations.

An important diagnostic tool in the estimation of the dynamic panel models is the number of used instruments. It is commonly taken that this number should not exceed the number of cross-sectional groups (firms). The number of instruments 
used is several times smaller than the number of groups (Table 5). Roodman (2009) also notes that the lagged value of the dependent variable estimated with a dynamic panel should lie between the values obtained with fixed effects panel and ordinary least squares (OLS) techniques. Our specification satisfies this condition as well. Bearing in mind everything stated, it can be concluded that all relevant diagnostics provide support to the model, which enables us to proceed with the estimation of results.

Table 6: Results of Estimation, Short-Run

\begin{tabular}{|c|c|}
\hline Variable & Value \\
\hline Lagged dependent variable & $0.29^{* * *}$ \\
\hline Strategic alliance member & $0.86^{* *}$ \\
\hline Firm size & $0.63^{* * *}$ \\
\hline Unit labor costs & $-1.07^{* * *}$ \\
\hline Unit material costs & $-2.59^{* * *}$ \\
\hline Ownership & -0.20 \\
\hline Localization externalities & 0.31 \\
\hline Urbanization externalities & $0.23^{*}$ \\
\hline Industrial concentration & 0.58 \\
\hline Control variable: Bosnia and Herzegovina & $5.50^{* * *}$ \\
\hline Control variable: The Czech Republic & $-2.01^{* * *}$ \\
\hline Control variable: Estonia & $3.91^{* * *}$ \\
\hline Control variable: Hungary & -0.67 \\
\hline Control variable: Poland & $10.08^{* * *}$ \\
\hline Control variable: Slovenia & $1.64^{* * *}$ \\
\hline Control variable: Slovakia & 0.36 \\
\hline Constant & 1.30 \\
\hline
\end{tabular}

Notes: ${ }^{* * *},{ }^{* *}$ and ${ }^{*}$ denote a statistical significance at 1,5 and 10 percent level, respectively; $p$-values estimated with two-step dynamic panel estimator with Windmeijer robust standard error corrections. Annual time dummies included. Source: Authors' calculations.

The coefficient of the lagged dependent variable is highly significant and positive (Table 6). This finding suggests that the current level of profitability depends also on its past realizations. The variable controlling for participation in strategic alliances is also positive and significant at the 5 percent significance level. This finding suggests that strategic alliances provide firms with benefits as those described earlier and pave the way for higher profitability. Among control 
variables, a positive coefficient is found for the firm's size and a negative one for both measures of unit costs. The former suggests that factors such as economies of scale or barriers to entry as well as improvements in cost efficiency facilitate the firm's profitability. Among features of firm environment, the coefficient on urbanization economies is significant at the 10 percent level. This finding suggests that between-industry externalities, such as sharing of basic infrastructure or easier access to demand, positively affect profitability. Finally, findings on country dummies suggest that compared to firms in Croatia, profitability is higher in Estonia, Poland, Slovenia, Slovakia and Bosnia and Herzegovina, while it is lower in the Czech Republic and Hungary.

The analysis of the long-run effects on profitability is undertaken with the delta method. All the results retain their significance and sign (Table 7). However, the magnitude of the coefficient is 1.4 times larger than the short-run coefficients. This suggests that the complete impact of strategic alliances and other variables on profitability is realized in the long run.

Table 7: Results of Estimation, Long-Run

\begin{tabular}{|c|c|}
\hline Variable & Value \\
\hline Strategic alliance member & $1.20^{* *}$ \\
\hline Firm size & $0.88^{* * *}$ \\
\hline Unit labor costs & $-1.51^{* * *}$ \\
\hline Unit material costs & $-3.61^{* * *}$ \\
\hline Ownership & -0.28 \\
\hline Localization externalities & 0.43 \\
\hline Urbanization externalities & $0.33^{*}$ \\
\hline Industrial concentration & 0.81 \\
\hline Control variable: Bosnia and Herzegovina & $7.69^{* * *}$ \\
\hline Control variable: The Czech Republic & $-2.82^{* * *}$ \\
\hline Control variable: Estonia & $5.47^{* * *}$ \\
\hline Control variable: Hungary & -0.93 \\
\hline Control variable: Poland & $14.10^{* * *}$ \\
\hline Control variable: Slovenia & $2.30^{* * *}$ \\
\hline Control variable: Slovakia & 0.50 \\
\hline
\end{tabular}

Notes: ${ }^{* * *},{ }^{* *}$ and ${ }^{*}$ denote a statistical significance at 1,5 and 10 percent level, respectively; $p$-values estimated with two-step dynamic panel estimator with Windmeijer robust standard error corrections. Annual time dummies included. Source: Authors' calculations. 


\subsection{Strategic Alliances and Firm Profitability in Croatia}

The previously described results point to a positive relationship between participation in strategic alliances and firm profitability in the analyzed countries. This part of the paper will focus on Croatian firms only. To this end, equation (4) is reduced in a way that excludes country dummy variables. Analogous to the previous section, the starting point of the analysis is the examination of model diagnostics (Table 8). All relevant diagnostics provide support to the chosen specification on the reduced sample as well. The Hansen test does not provide sufficient evidence to reject the null hypothesis on instrument validity. The Arellano-Bond tests point to the existence of first order autocorrelation and the absence of second order autocorrelation. The number of used instruments is several times lower than the number of groups (firms) in the estimation, while the estimated coefficient of the lagged dependent variable is larger than the one obtained with the fixed effects panel and smaller than the OLS-produced coefficient. All of this enables us to proceed with the interpretation of findings.

Table 8: Model Diagnostics

\begin{tabular}{l|c}
\hline Diagnostics & Value \\
\hline Number of observations & 10,545 \\
\hline Number of groups (firms) & 2,449 \\
\hline Number of instruments & 24 \\
\hline Wald test & $700.67^{* * *}$ \\
\hline Hansen $J$ test & 11.97 \\
\hline p $>$ chi2 & 0.215 \\
\hline Arellano-Bond test first order & -12.65 \\
\hline p >chi2 & 0.000 \\
\hline Arellano-Bond test second order & 0.19 \\
\hline p $>$ chi2 & 0.853 \\
\hline Lagged dependent variable: fixed effects panel & $0.04^{* * *}$ \\
\hline Lagged dependent variable: dynamic panel & $0.29^{* * *}$ \\
\hline Lagged dependent variable: OLS & $0.44^{* * *}$ \\
\hline
\end{tabular}

Note: ${ }^{* * *},{ }^{* *}$ and ${ }^{*}$ denote a statistical significance at 1,5 and 10 percent level, respectively.

Source: Authors' calculations. 
Results of the estimation are presented in Table 9. In line with the earlier findings, the coefficient of the lagged dependent variable is highly significant and positive, suggesting that previous profitability values have a positive influence on current realizations. Participation in a strategic alliance also positively influences profitability. The magnitude of the coefficient is somewhat lower than for the sample of all countries.

Table 9: Results of Estimation

\begin{tabular}{|c|c|c|}
\hline Variable & Short-run & Long-run \\
\hline Lagged dependent variable & $0.29^{* * *}$ & - \\
\hline Strategic alliance member & $0.76^{*}$ & $1.06^{*}$ \\
\hline Firm size & $0.75^{* * *}$ & $1.05^{* * *}$ \\
\hline Unit labor costs & $-5.45^{* * *}$ & $-7.62^{* * *}$ \\
\hline Unit material costs & $-7.85^{* * *}$ & $-10.98^{* * *}$ \\
\hline Ownership & 0.03 & 0.05 \\
\hline Localization externalities & 0.67 & 0.94 \\
\hline Urbanization externalities & $0.70^{* * *}$ & $0.98^{* * *}$ \\
\hline Industrial concentration & $-0.63^{* *}$ & $-0.88^{* *}$ \\
\hline Constant & $-9.84^{* * *}$ & - \\
\hline
\end{tabular}

Notes: ${ }^{* * *},{ }^{* *}$ and ${ }^{*}$ denote a statistical significance at 1,5 and 10 percent level, respectively; $p$-values estimated with two-step dynamic panel estimator with Windmeijer robust standard error corrections. Annual time dummies included. Source: Authors' calculations.

Among control variables, the only difference in relation to the earlier model is the significance of the coefficient on industrial concentration. Larger firms and cost-efficient ones are more profitable. The impact of urbanization economies is positive, while industrial concentration negatively influences profitability. All variables retain their significance and sign in the long run, with the magnitude of the coefficient about 1.4 times larger than the short-run coefficients. 


\section{Conclusions}

One of the most important objectives of business entities is the achievement of returns on their activities. There is a widespread consensus among economists that the desire for higher profitability represents one of the driving forces of overall economic activity in market economies. However, while traditional economics defines differences in profitability as a transitory feature of a firm's behavior and predicts convergence of business entities toward normal profit levels, alternative economic schools of thought suggest that some firms can outperform others over a considerable period of time. Throughout decades, research attempted to identify the factors behind the differences in profitability of business entities. The results of these investigations point to several groups of factors, such as the characteristics of the business entities, features of their industries and institutional factors.

To reiterate, the objective of this paper was to explore the impact of strategic alliance membership on the profitability of business entities in the retail sector in a number of Central, East and Southeast European countries (CESEE) with a particular emphasis on Croatia. To this end, a model was applied that takes into account the dynamics of profitability, potential endogeneity due to correlation between the dependent variable and time-invariant unobservables, and the distinction between short- and long-run effects of variables on profitability. To the best of our knowledge, the research represents the first step as such in the investigation of firm behavior in the retail sector. The results of the investigation provide support to the assumption about the persistence of profitability. Business entities that are more successful than their rivals retain their supremacy in the long run as well. Such a finding is consistent with the assumptions of the alternative economic schools of thought.

The most important finding concerns the relationship between strategic alliance membership and profitability. From the obtained results one can conclude that factors such as cost sharing, risk diversification and knowledge transfer, 
recognized in the existing literature as positive externalities of strategic alliances, contribute to the profitability of business entities in the retail sectors of the analyzed countries. It is worth emphasizing that the effect of strategic alliances on profitability is not restricted to the short run, but extends in the long run. Our findings reveal a number of other determinants of profitability as well. The size of business entities, cost efficiency and between-industry agglomeration externalities all positively influence profitability. The obtained findings hold for the subsample of Croatian firms as well.

\section{Literature}

Alchian, Armen Albert, 1950, "Uncertainty, Evolution, and Economic Theory”, The Journal of Political Economy, 58(3), pp. 211-221. https://oi. org/10.1086/256940

Anić, Ivan-Damir and Mustafa Nušinović, 2003, "Croatian Retailing in Transition towards European Retailing - Differences, Convergence and Perspectives", Privredna kretanja i ekonomska politika, 13(96), pp. 71-92.

Antoncic, Bostjan and Igor Prodan, 2008, "Alliances, Corporate Technological Entrepreneurship and Firm Performance: Testing a Model on Manufacturing Firms", Technovation, 28(5), pp. 257-265. https://doi.org/10.1016/j. technovation.2007.07.005

Arellano, Manuel and Stephen Bond, 1991, "Some Tests of Specification for Panel Data: Monte Carlo Evidence and an Application to Employment Equations", The Review of Economic Studies, 58(2), pp. 277-297. https://doi.org/10.2307/2297968

Bae, Jonghoon and Martin Gargiulo, 2004, "Partner Substitutability, Alliance Network Structure, and Firm Profitability in the Telecommunications Industry", Academy of Management Journal, 47(6), pp. 843-859. https://doi. org/10.2307/20159626 
Bain, Joe Staten, 1951, "Relation of Profit Rate to Industry Concentration: American Manufacturing, 1936-1940”, The Quarterly Journal of Economics, 65(3), pp. 293-324. https://doi.org/10.2307/1882217

Bain, Joe Staten, 1956, Barriers to New Competition: Their Character and Consequences in Manufacturing Industries, Cambridge, MA: Harvard University Press. https://doi.org/10.4159/harvard.9780674188037

Barney, Jay, 1991, "Firm Resources and Sustained Competitive Advantage", Journal of Management, 17(1), pp. 99-120. https://doi.org/10.1177/ 014920639101700108

Blundell, Richard and Stephen Bond, 1998, "Initial Conditions and Moment Restrictions in Dynamic Panel Data Models", Journal of Econometrics, 87(1), pp. 115-143. https://doi.org/10.1016/S0304-4076(98)00009-8

Buckley, Peter Jennings, Christopher L. Pass and Kate Prescott, 1988, "Measures of International Competitiveness: A Critical Survey", Journal of Marketing Management, 4(2), pp. 175-200. https://doi.org/10.1080/026725 7X.1988.9964068

Cubbin, John and Paul Geroski, 1990, "The Persistence of Profits in the United Kingdom" in Dennis C. Mueller, ed., The Dynamics of Company Profits: An International Comparison, pp. 147-167, Cambridge: Cambridge University Press. https://doi.org/10.1017/CBO9780511664724.010

Daft, Richard L., 1986, Organization Theory and Design, St. Paul, MN: West Publishing Company.

Das, Tushar K. and Bing-Sheng Teng, 2000, "A Resource-Based Theory of Strategic Alliances", Journal of Management, 26(1), pp. 31-61. https://doi. org/10.1177/014920630002600105

Djankov, Simeon and Peter Murrell, 2002, "Enterprise Restructuring in Transition: A Quantitative Survey", Journal of Economic Literature, 40(3), pp. 739-792. https://doi.org/10.1257/jel.40.3.739 
Dunković, Dario, 2017, "Rivalry of Domestic and Foreign Retailers in Croatia", Management: Journal of Contemporary Management Issues, 9(2), pp. 75-96.

Goddard, John, Manouche Tavakoli and John O. S. Wilson, 2005, "Determinants of Profitability in European Manufacturing and Services: Evidence from a Dynamic Panel Model", Applied Financial Economics, 15(18), pp. 1269-1282. https://doi.org/10.1080/09603100500387139

Goerzen, Anthony, 2007, “Alliance Networks and Firm Performance: The Impact of Repeated Partnerships", Strategic Management Journal, 28(5), pp. 487-509. https://doi.org/10.1002/smj.588

Greene, William H., 2002, Econometric Analysis, Upper Saddle River, NJ: Prentice Hall.

Grossman, Gene M. and Elhanan Helpman, 1994, "Endogenous Innovation in the Theory of Growth", The Journal of Economic Perspectives, 8(1), pp. 23-44. https://doi.org/10.1257/jep.8.1.23

Gulati, Ranjay and Harbir Singh, 1998, “The Architecture of Cooperation: Managing Coordination Costs and Appropriation Concerns in Strategic Alliances", Administrative Science Quarterly, 43(4), pp. 781-814. https://doi. org/10.2307/2393616

Harrigan, Kathryn Rudie, 1986, Managing for Joint Venture Success, Lexington, MA: Lexington Books.

Hashi, Iraj and Nebojša Stojčić, 2013, “The Impact of Innovation Activities on Firm Performance Using a Multi-Stage Model: Evidence from the Community Innovation Survey 4", Research Policy, 42(2), pp. 353-366. https://doi. org/10.1016/j.respol.2012.09.011

Havlik, Peter, 2000, "Trade and Cost Competitiveness in the Czech Republic, Hungary, Poland, and Slovenia”, World Bank Technical Paper, No. 482, Washington, DC: The World Bank. https://doi.org/10.1596/0-8213-4796-9 
Hitt, Michael A., Tina M. Dacin, Edward Levitas, Jean-Luc Arregle and Anca Borza, 2000, "Partner Selection in Emerging and Developed Market Contexts: Resource-Based and Organizational Learning Perspectives", Academy of Management Journal, 43(3), pp. 449-467. https://doi.org/10.2307/1556404

Jacobs, Jane, 1969, The Economy of Cities, New York, NY: Random House.

Kirzner, Israel M., 1997, "Entrepreneurial Discovery and the Competitive Market Process: An Austrian Approach", Journal of Economic Literature, 35(1), pp. 60-85.

Knight, Frank H., 1921, Risk, Uncertainty and Profit, Boston, MA: Houghton Mifflin.

Kogut, Bruce and Udo Zander, 1992, "Knowledge of the Firm, Combinative Capabilities, and the Replication of Technology", Organization Science, 3(3), pp. 383-397. https://doi.org/10.1287/orsc.3.3.383

Lado, Augustine A., Nancy G. Boyd and Susan C. Hanlon, 1997, "Competition, Cooperation, and the Search for Economic Rents: A Syncretic Model”, Academy of Management Review, 22(1), pp.110-141.

Lee, Cheng-Wen, 2007, "Strategic Alliances Influence on Small and Medium Firm Performance", Journal of Business Research, 60(7), pp. 731-741. https://doi. org/10.1016/j.jbusres.2007.02.018

Lin, Zhiang John, Haibin Yang and Bindu Arya, 2009, "Alliance Partners and Firm Performance: Resource Complementarity and Status Association”, Strategic Management Journal, 30(9), pp. 921-940. https://doi.org/10.1002/smj.773

Lööf, Hans and Almas Heshmati, 2002, "Knowledge Capital and Performance Heterogeneity: A Firm-Level Innovation Study", International Journal of Production Economics, 76(1), pp. 61-85. https://doi.org/10.1016/S09255273(01)00147-5

Lööf, Hans and Almas Heshmati, 2006, "On the Relationship between Innovation and Performance: A Sensitivity Analysis", Economics of Innovation and New Technology, 15(4/5), pp. 317-344. https://doi.org/10.1080/10438590500512810 
Lu, Jane W. and Paul W. Beamish, 2006, "Partnering Strategies and Performance of SMEs' International Joint Ventures”, Journal of Business Venturing, 21(4), pp. 461-486. https://doi.org/10.1016/j.jbusvent.2005.02.002

Luo, Xueming, Aric Rindfleisch and David K. Tse, 2007, "Working with Rivals: The Impact of Competitor Alliances on Financial Performance", Journal of Marketing Research, 44(1), pp. 73-83. https://doi.org/10.1509/jmkr.44.1.73

Marshall, Alfred, 1920, Principles of Economics, London: Macmillan.

McMillan, David G. and Mark E. Wohar, 2011, "Profit Persistence Revisited: The Case of the UK”, The Manchester School, 79(3), pp. 510-527. https://doi. org/10.1111/j.1467-9957.2010.02177.x

Nelson, Richard R. and Sidney G. Winter, 1982, An Evolutionary Theory of Economic Change, Cambridge, MA: Belknap Press.

Oum, Tae H., Jong-Hun Park, Kwangsoo Kim and Chunyan Yu, 2004, "The Effect of Horizontal Alliances on Firm Productivity and Profitability: Evidence from the Global Airline Industry", Journal of Business Research, 57(8), pp. $844-$ 853. https://doi.org/10.1016/S0148-2963(02)00484-8

Papke, Leslie E. and Jeffrey M. Wooldridge, 2005, "A Computational Trick for Delta-Method Standard Errors", Economics Letters, 86(3), pp. 413-417. https:// doi.org/10.1016/j.econlet.2004.07.022

Porter, Michael E. and Mark B. Fuller, 1986, "Coalitions and Global Strategy" in Michael E. Porter, ed., Competition in Global Industries, pp. 15-60, Boston, MA: Harvard Business School Press.

Reijnders, Will J. M. and Theo M. M. Verhallen, 1996, "Strategic Alliances among Small Retailing Firms: Empirical Evidence for the Netherlands", Journal of Small Business Management, 34(1), pp. 36-45.

Roodman, David, 2009, "How to Do xtabond2: An Introduction to Difference and System GMM in Stata”, Stata Journal, 9(1), pp. 86-136. 
Rugraff, Eric, 2006, "Export-Oriented Multinationals and the Quality of International Specialisation in Central European Countries", The European Journal of Development Research, 18(4), pp. 642-661. https://doi. org/10.1080/09578810601070985

Schadler, Susan, Ashoka Mody, Abdul Abiad and Daniel Leigh, 2006, "Growth in the Central and Eastern European Countries of the European Union", IMF Occasional Paper, No. 252, Washington, DC: International Monetary Fund.

Schumpeter, Joseph Alois, 1942, Capitalism, Socialism and Democracy, New York, NY: Harper and Row.

Slade, Margaret E., 2004, "Competing Models of Firm Profitability", International Journal of Industrial Organization, 22(3), pp. 289-308. https://doi. org/10.1016/j.ijindorg.2003.12.001

Stojčić, Nebojša, 2012, "Theoretical Foundations and Measurement of Competitiveness", Poslovna izvrsnost, 6(2), pp. 143-166.

Stojčić, Nebojša, Iraj Hashi and Shqiponja Telhaj, 2013, "Restructuring and Competitiveness: Empirical Evidence on Firm Behavior in New EU Member States and Candidate Countries", Eastern European Economics, 51(4), pp. 84107. https://doi.org/10.2753/EEE0012-8775510404

Stojčić, Nebojša and Katija Vojvodić, 2012, "Determinants of Profitability of Firms in the Retail Sector: The Case of Croatia", Conference Proceedings of the $8^{\text {th }}$ International Conference "Interdisciplinary Management Research", Opatija, May 11-13, pp. 849-860, Osijek: Faculty of Economics, Osijek.

Von Mises, Ludwig, 1949, Human Action, New Haven, CT: Yale University Press.

Windmeijer, Frank, 2005, "A Finite Sample Correction for the Variance of Linear Efficient Two-Step GMM Estimators”, Journal of Econometrics, 126(1), pp. 25-51. https://doi.org/10.1016/j.jeconom.2004.02.005

Zollo, Maurizio, Jeffrey J. Reuer and Harbir Singh, 2002, "Interorganizational Routines and Performance in Strategic Alliances", Organization Science, 13(6), pp. 701-713. https://doi.org/10.1287/orsc.13.6.701.503 